\title{
Thermal manipulation of the broilers embryos: expression of muscle markers genes and weights of body and internal organs during embryonic and post-hatch days
}

Mohamed Borhan Al-Zghoul ${ }^{1 *}$ and Sabry Mohamed El-Bahr ${ }^{2,3^{*}}$ (D)

\begin{abstract}
Background: In broilers chickens, the molecular bases for promoting muscle development and growth requires further investigation. Therefore, the current study aimed to investigate the effects of daily thermal manipulation (TM) during embryonic days (ED) 12 to 18 on body, carcass and internal organ weights as well as on the expression of muscle growth markers genes during late embryogenesis and post-hatch days. 1500 fertile Cobb eggs were divided into five groups. The first group was a control group and incubated at $37.8^{\circ} \mathrm{C}$. The other four groups were thermally manipulated (TM) and exposed to $38.5^{\circ} \mathrm{C}\left(\mathrm{TM}_{1}\right), 39^{\circ} \mathrm{C}\left(\mathrm{TM}_{2}\right), 39.5^{\circ} \mathrm{C}\left(\mathrm{TM}_{3}\right)$ and $40^{\circ} \mathrm{C}\left(\mathrm{TM}_{4}\right)$ daily for $18 \mathrm{~h}$, respectively, with a relative humidity of 56\%. Body weights (BW) from ED 12 to 18 and on post-hatch days 1, 2, 3, 4, $5,6,7,14,21,28$ and 35 were recorded. mRNA expression levels of muscle growth factor genes (IGF-1 and GH) and muscle marker genes (Myogenic Differentiation Antigen; MyoD), Myogenin, Pax7, and PCNA) during ED 12 to 18 and on post-hatch days 1, 3, 5, 7, 14 were analyzed. On post-hatch day 35, the carcass and internal organ weights have been also evaluated.
\end{abstract}

Results: TM during certain days of embryogenesis (ED 12 to 18) did not affect the BW of broilers during their embryonic lives. However, $\mathrm{TM}$, particularly $\mathrm{TM}_{1}$ and $\mathrm{TM}_{2}$, significantly increased BW, carcass and internal weights of hatched chicks near to the marketing age (post-hatch days 28 and 35). Most of TM protocols induced up-regulation of muscle growth factor genes (IGF-1 and GH) and muscle marker genes (MyoD, Myogenin, Pax7, and PCNA) during embryonic life (ED 12 to 18) and on post-hatch days.

Conclusion: Among the various TM conditions, it seems that, $\mathrm{TM}_{1}$ and $\mathrm{TM}_{2}$ induced a significant increase in BW, carcass and internal weights of hatched chicks near to the marketing age. This increase in BW induced presumably via up-regulation of muscle growth factor genes and muscle growth markers genes during embryonic life (ED 12 to 18) and on post-hatch days. Both protocols (TM $\mathrm{TM}_{1}$ and $\left.\mathrm{TM} 2\right)$ can be used in real-world applications of poultry industry for maximum benefit.

Keywords: Muscle, Marker gene, Growth factor, Broiler, Thermal manipulation

\footnotetext{
*Correspondence: alzghoul@just.edu.jo; selbahar@kfu.edu.sa

'Department of Basic Medical Veterinary Sciences, Faculty of Veterinary

Medicine, Jordan University of Science and Technology, P.O. Box 3030, Irbid

22110, Jordan

2Department of Physiology, Biochemistry and Pharmacology, College of

Veterinary Medicine, King Faisal University, P.O. Box 400, Al-Hufof 31982,

Saudi Arabia

Full list of author information is available at the end of the article
}

(c) The Author(s). 2019 Open Access This article is distributed under the terms of the Creative Commons Attribution 4.0 International License (http://creativecommons.org/licenses/by/4.0/), which permits unrestricted use, distribution, and

reproduction in any medium, provided you give appropriate credit to the original author(s) and the source, provide a link to the Creative Commons license, and indicate if changes were made. The Creative Commons Public Domain Dedication waiver (http://creativecommons.org/publicdomain/zero/1.0/) applies to the data made available in this article, unless otherwise stated. 


\section{Background}

The rates and efficiencies of muscle tissue deposition vary widely among domestic animals [1, 2]. In muscle cells, as in a variety of cell types, a balance of opposing cellular signals controls proliferation and differentiation [3]. At birth, a high number of proliferating satellite cells are found in skeletal muscle nuclei; however, at the end of the growth phase, their numbers are reduced to less than $5 \%$ of total muscle fiber nuclei [4]. The musclespecific basic helix-loop-helix (bHLH) proteins, a family of transcription factors, regulate the proliferation and differentiation of myoblasts [5]. Upon satellite cell activation, these transcription factors are expressed in a sequential pattern [6]. Initially, Myogenic factor-5 (Myf5) and Myogenic Differentiation Antigen (MyoD) are expressed in the proliferating progeny, followed by myogenin expression as the cells begin to differentiate [7].

Thermal manipulation (TM) has been proposed as a technique to enhance muscle growth and to improve the thermotolerance acquisition of the broiler chicken, in which the embryos are exposed to high or low temperatures during the susceptible period of their lives [8-15]. Previously, it has been shown that the incubation temperature has a significant effect on hatchability rate, chick quality, and post-hatch growth performance parameters [16, 17]. Thermal manipulation (TM) of chicken embryos induced differential gene expression in response to post-hatching heat challenge [18]. In addition, TM immediately affects miRNA expression profiles of breast and hind muscles of chicken embryos and is associated with minor long term expression of miRNAs broiler chickens [19]. However, the molecular bases for promoting muscle development and growth requires further investigation $[12,13,16,20]$. Therefore, the current study aimed to investigate the effect of different daily $\mathrm{TM}$ conditions, namely $\mathrm{TM}_{1}\left(38.5^{\circ} \mathrm{C}\right.$ for $18 \mathrm{~h}), \mathrm{TM}_{2}\left(39^{\circ} \mathrm{C}\right.$ for $\left.18 \mathrm{~h}\right), \mathrm{TM}_{3}\left(39.5^{\circ} \mathrm{C}\right.$ for $\left.18 \mathrm{~h}\right)$ and $\mathrm{TM}_{4}\left(40^{\circ} \mathrm{C}\right.$ for $\left.18 \mathrm{~h}\right)$ during embryonic days (ED) 12 to 18 , on body (BW) and internal organ weights and expression of muscle growth and transcription factor genes of broiler chickens. The muscle growth factor genes included insulin-like growth factor 1 (IGF-1) and growth hormone $(\mathrm{GH})$, while the muscle marker genes encompassed MyoD, myogenin, paired box transcription factor (Pax7), and proliferating cell nuclear antigen (PCNA) during late embryogenesis and post-hatch days. The results of this study provide an insight into the molecular basis of muscle development and growth of thermally-manipulated (TM) broilers.

\section{Methods}

Incubation and hatching management

All experimental procedures and management conditions used in this study were approved by Jordan
University of Science and Technology's Animal Care and Use Committee (JUST-ACUC). 1700 fertile Ross broiler eggs were obtained from a certified Ross breeder flock of hens (Irbid, Jordan). The eggs were examined for breakage or any abnormality, with very small $(<59 \mathrm{~g})$ and large eggs $(>68 \mathrm{~g}$ ) being rejected. 1500 normal eggs with an initial weight of $64 \pm 2 \mathrm{~g}$ were then selected and incubated in five commercial incubators (Type 25 HS-SSF, Masalles, Barcelona, Spain). The incubators are of continuous turning system, fully digital programmable temperature (room to $70^{\circ} \mathrm{C}$ ) and humidity (20-95\%) equipped with fully automated cooling system of self control Natural Cool Down Programmable (NCDP) which avoid temperature swing and equipped with alarm in case of overheating. The temperature inside the incubator was fluctuated with $\pm 0.1^{\circ} \mathrm{C}$. The incubator equipped with digital electronic thermostat high precision. The selected eggs were then equally allocated to the following five incubation treatment groups (300 eggs in each group): control group (maintained at $37.8^{\circ} \mathrm{C}$ and $56 \%$ relative humidity $(\mathrm{RH})$ throughout the incubation period); $\mathrm{TM}_{1}$ (daily $\mathrm{TM}$ at $38.5^{\circ} \mathrm{C}$ and $65 \% \mathrm{RH}$ for $18 \mathrm{~h}$ on ED 12 to 18 ); $\mathrm{TM}_{2}$ (daily $\mathrm{TM}$ at $39^{\circ} \mathrm{C}$ and $65 \% \mathrm{RH}$ for $18 \mathrm{~h}$ on $\mathrm{ED} 12$ to 18 ); $\mathrm{TM}_{3}$ (daily $\mathrm{TM}$ at $39.5^{\circ} \mathrm{C}$ and 65\% RH for $18 \mathrm{~h}$ on ED 12 to 18 ); and $\mathrm{TM}_{4}$ (daily TM at $40^{\circ} \mathrm{C}$ and $65 \% \mathrm{RH}$ for $18 \mathrm{~h}$ on ED 12 to 18 ). TM1-TM4 were incubated like the control condition $\left(37.8^{\circ} \mathrm{C} ; 56 \%\right.$ $\mathrm{RH})$ during the last $6 \mathrm{~h}$ of the day. Eggs were placed randomly at various locations of the incubators. At hatch, the number of hatched chicks was recorded. In addition, the hatchability (\%) was calculated by dividing the number of healthy chicks by the total number of fertilised eggs. One-day old chicks were then transferred to the Animal House at Jordan University of Science and Technology where the experiment was conducted. Chicks were distributed in cages with a starting room temperature of $33^{\circ} \mathrm{C}$ that was gradually decreased to $24^{\circ} \mathrm{C}$ on post hatch day 21 . From post-hatch day 24 to 35 , the temperature was maintained at $21^{\circ} \mathrm{C}$. Water and feed were supplied to the chicks ad libitum.

\section{Sample collection}

Pectoral and thigh muscle samples were collected from 100 embryos (10 embryos from each treatment group per day on ED 12 and 18) and from 300 chicks (10 chicks from each treatment group per day on post-hatch days $1,3,5,7,14$ and 28). Euthanasia was performed after sodium pentobarbital anesthesia $(20-30 \mathrm{mg} / \mathrm{kg}$; [21]). Sodium pentobarbital was injected to radial vein with sterilized needles. Pectoral muscle mRNA expression levels of muscle marker genes (MyoD, Myogenin, Pax7 and PCNA) and muscle growth factors (IGF-1 and $\mathrm{GH}$ ) were evaluated using relative quantitative real-time polymerase chain reaction (qRT-PCR) analyses. 
At ED 12 and 18, ten embryos from each group were individually weighed using a $0.01 \mathrm{~g}$ precision scale. Chicks $(n=20)$ were individually weighed on a daily basis during the post-hatch first week and then on posthatch days 14, 21, 28 and 35 of age. At post-hatch day 35, 10 birds from each group were euthanized, and the weights of their hearts, lungs, spleens, livers, intestines, and gizzards as well as the lengths of their intestines, caeca, and colons were recorded.

\section{RNA isolation and qRT-PCR analysis}

Total RNA was extracted from homogenated muscles tissues using a TRIzol/choloroform/isopropanol method followed by the removal of supernatants. The RNA pellet was then dissolved in diethylpyrocarbonate treated RNase-free water (Ambion, Texas, USA). DNA was digested using the DNase I kit (Ambion, Austin, TX), and RNA samples were checked for concentration and purity (260:280 nm absorbency). $2 \mu \mathrm{g}$ RNA was reverse transcribed to create cDNA using the iScript cDNA Synthesis Kit (Bio-Rad, Hercules, CA, USA). qRT-PCR was performed using a QuantiFast SYBR ${ }^{\circ}$ Green PCR Kit (Qiagen, Valencia, CA, USA) on a Rotor-Gene Q Real-Time PCR system (Qiagen, Valencia, CA, USA). Briefly, the $20 \mu \mathrm{l}$ reaction mix was prepared from $10 \mu \mathrm{l}$ of master mix; $2 \mu \mathrm{l}$ forward primer $(10 \mathrm{pmol}) ; 2 \mu \mathrm{l}$ reverse primer $(10 \mathrm{pmol})$; $2 \mu \mathrm{l}$ cDNA of the sample and $6.5 \mu \mathrm{l}$ of nuclease-free water. Cycling parameters were $50^{\circ} \mathrm{C}$ for $2 \mathrm{~min}, 95^{\circ} \mathrm{C}$ for $15 \mathrm{~min}$, 40 cycles of $95^{\circ} \mathrm{C}$ for $10 \mathrm{~s}$, followed by $30 \mathrm{~s}$ at $55^{\circ} \mathrm{C}$ and $72^{\circ} \mathrm{C}$ for 10 s with final melting at $95^{\circ} \mathrm{C}$ for 20s. Post-PCR melting curves confirmed the specificity of single-target amplification, and fold changes in gene expressions were normalized to the housekeeping gene GAPDH. Duplicates from each cDNA was analyzed, fluorescence emission was detected and relative quantification was calculated automatically. The primer sequences that were used in the qRT-PCR analyses are illustrated in Table 1.

\section{Statistical analysis}

All statistical analyses were performed using IBM SPSS statistics 23 software (IBM software, Chicago, USA). Hatchability was analyzed by the Chi-square test. Data for BW, internal organ weights, muscle marker and growth factor gene expression were conveyed in means \pm SD. One-way ANOVA followed by the all-pairs Bonferroni test was used to compare different parameters in all treatment groups, and differences were considered significant at $P<0.05$.

\section{Results}

Effect of thermal manipulation on hatchability and embryonic and post-hatch body weight

Eggs from which embryos taken for measurement of embryonic mRNA levels of muscle growth markers
Table 1 Primers for relative-quantitative real time RT-PCR analyses

\begin{tabular}{ll}
\hline Gene & Sequence \\
\hline cGAPDH & F-5'GTGTTATCATCTCAGCTCCCTCAG'3 \\
cGAPDH & R-5'GGTCATAAGACCCTCCA CAATG3' \\
cIGF-1 & F-5'GTGTTGCTTACCTAACCAGT' '3 \\
cIGF-1 & R-5'GTACAGAGC GTGCAGATT'3 \\
cGH & F-5' GACCAGAGGTACACCAACAAA3' \\
cGH & R-5'GACTGGATGAGAACCAGTGAAA3' \\
cMyoD & F-5'TACCCAGTGCTGGAGCACTA'3 \\
cMyoD & R5'GTCTTGGA GCTTGGCTGAACT'3 \\
cMyogenin & F-5'AGCAGCCTCAACCAGCAGGA'3 \\
cMyogenin & R-5'TCT GCCTGGTCATCGCTCAG'3 \\
cPAX7 & F-5'ACTGTGCCCTCAGTGAGTCGAT'3 \\
cPAX7 & R-5'ATTCGACATCGGAGCCTTCATCCA '3 \\
cPCNA & F-5'ACGCATTGTAGAGACC TCAGCCA \\
cPCNA & R-5'AGTCAGCTGGACTGGCTCATTCAT'3
\end{tabular}

GAPDH, glyceraldehyde 3-phosphate dehydrogenase; IGF-1, insulin-like growth factor $1 ; G H$, growth hormone; MyoD, myogenic differentiation gene; Pax 7 , paired box transcription factor; PCNA, proliferating cell nuclear antigen

genes and were excluded from the hatchability results. The effect of TM during embryogenesis on hatchability is summarized in Table 2. The total number of hatched eggs after 21 days of incubation was 1045. TM1 and TM2 did not affect the hatchability percentage and remained comparable to that of the control. However, TM3 and TM4 reduced the hatchability percentage compare to control, TM1 and TM2.

The effect of TM on embryonic BW is shown in Fig. 1. Similar embryonic BW were observed for both the treatment and control groups. The BW of chicks in the post-hatch period (first week of age and post-hatch day 10,14,21, 28 and 35) is shown in Fig. 2. TM chicks exhibited an advantage over controls up to 35 day of age with regard to BW. On post-hatch day $1, \mathrm{BW}$ of chicks in the $\mathrm{TM}_{1}$ and $\mathrm{TM}_{4}$ groups were significantly $(p<0.05)$ higher than those in the $\mathrm{TM}_{2}$ and $\mathrm{TM}_{3}$ groups, both of which remained comparable to controls. On post-hatch day 2 and 3 , the BW of all treatments were comparable to the controls $(p>0.05)$. On post-hatch day 4 , BW of the $\mathrm{TM}_{4}$ group was significantly $(p<0.05)$ higher than that of the other treatment groups which remained comparable to the control group. On posthatch day $5, \mathrm{BW}$ of the $\mathrm{TM}_{3}$ group was significantly $(p<0.05)$ higher than that of other treatment groups which remained comparable to the controls. On post-hatch days 6,7 , and $10, \mathrm{BW}$ of $\mathrm{TM}_{3}$ and $\mathrm{TM}_{4}$ groups were significantly $(p<0.05)$ higher than that of the $\mathrm{TM}_{1}$ and $\mathrm{TM}_{2}$ groups. On post-hatch day 21, the $\mathrm{BW}$ of the $\mathrm{TM}_{1}$ and $\mathrm{TM}_{3}$ groups was 
Table 2 The effect of thermal manipulation (TM) on hatchability in broiler chicks subjected to different thermal manipulation treatments during embryogenesis

\begin{tabular}{llllll}
\hline Parameters & Groups & & & \\
\cline { 2 - 5 } & Control & $\mathrm{TM}_{1}$ & $\mathrm{TM}_{2}$ & $\mathrm{TM}_{3}$ & \\
\hline Non-hatched eggs & $38(16.24 \%)$ & $41(16.27 \%)$ & $42(16.67 \%)$ & $62(22.46 \%)$ & $64(23.03 \%)$ \\
Total (hatch) & $196 / 234$ & $211 / 252$ & $210 / 252$ & $214 / 276$ & $214 / 278$ \\
Hatchability \% & $83.76^{\mathrm{a}}$ & $83.73^{\mathrm{a}}$ & $83.33^{\mathrm{a}}$ & $77.53^{\mathrm{b}}$ & $76.97^{\mathrm{b}}$ \\
\hline
\end{tabular}

a-b Within the same ED, means \pm SD with different superscripts differ significantly $(P<0.05)$

significantly $(p<0.05)$ higher when compared with the other treatment groups. Interestingly, on posthatch day 28 and $35, \mathrm{BW}$ of the $\mathrm{TM}_{1}$ and $\mathrm{TM}_{2}$ groups was significantly $(\mathrm{p}<0.05)$ higher than that of other TM groups (Fig. 2 and Table 3 ).

\section{Effect of thermal manipulation on post-hatch internal organs weights}

On post-hatch day 35, TM induced a significant $(p<$ 0.05 ) increase in carcass weight, breast muscle weight, breast weight/carcass weight percentage and liver weight compared to control (Table 3). On post-hatch day 35, carcass weight of the $\mathrm{TM}_{1}$ and $\mathrm{TM}_{2}$ groups was significantly $(\mathrm{p}<0.05)$ higher than that of other TM groups (Table 3). Interterestingly, on post-hatch day 35, the heart weight and colon length of $\mathrm{TM}_{1}$ and $\mathrm{TM}_{2}$ were higher $(p<0.05)$ than whose of other treatment and control groups (Table 3). However, on post-hatch 35, lung, spleen, and intestine weights as well as intestine and cecum lengths were not changed $(p>0.05)$ in all TM groups compared to controls (Table 3 ). Finally, on posthatch day 35 , gizzard weights of those in the $\mathrm{TM}_{3}$ group

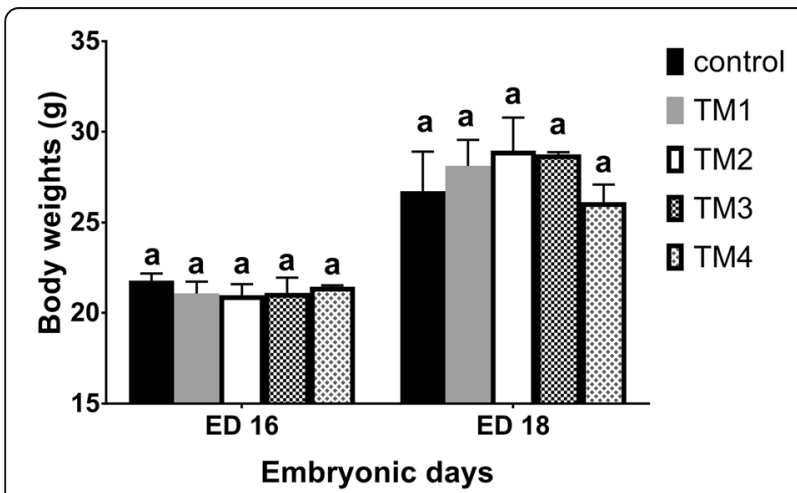

Fig. 1 The effect of thermal manipulation (TM) on embryonic body weight in broiler chicks subjected to different thermal manipulation treatments during embryogenesis) $n=3$ ). Control $=37.8^{\circ} \mathrm{C}$ for $24 \mathrm{~h}$; $\mathrm{TM}_{1}=$ Thermal manipulation at $38.5^{\circ} \mathrm{C}$ for $18 \mathrm{~h} ; \mathrm{TM}_{2}=$ Thermal manipulation at $39^{\circ} \mathrm{C}$ for $18 \mathrm{~h}$; $\mathrm{TM}_{3}=$ Thermal manipulation at $39.5^{\circ} \mathrm{Cfor}$ $18 \mathrm{~h}, \mathrm{TM}_{4}=$ Thermal manipulation at $40^{\circ} \mathrm{C}$ for $18 \mathrm{~h}$. ${ }^{\mathrm{a}-\mathrm{b}}$ Within the same ED, means \pm SD with different superscripts differ significantly $(P<0.05)$ was higher $(p<0.05)$ than that of the other TM and control groups (Table 3).

Effects of thermal manipulation on mRNA expression levels of muscle growth factors (IGF-1 and GH) and muscle marker genes (MyoD, Myogenin, Pax7 and PCNA) on ED 12 and 18

The effects of TM on mRNA expression levels of muscle growth factors and marker genes on ED 12 and 18 are illustrated in Table 4. On ED 12, TM induced significant elevation of MyoD levels except for $\mathrm{TM}_{3}$, which remained comparable to controls. Furthermore, TM induced significant $(\mathrm{p}<0.05)$ elevation to myogenin level compared to control except for $\mathrm{TM}_{3}$ which reduced the expression of this gene. Furtherly, $\mathrm{TM}_{3}$ and $\mathrm{TM}_{4}$ significantly induced IGF-1 upregulation, while $\mathrm{TM}_{1}$ and $\mathrm{TM}_{2}$ downregulated the expression of this gene compared to controls. In addition, $\mathrm{TM}_{1}, \mathrm{TM}_{2}$ and $\mathrm{TM}_{3}$ increased the $\mathrm{GH}$ level compared to $\mathrm{TM}_{4}$ which remained comparable to the control (Table 4). $\mathrm{TM}_{2}$ induced overexpression of this gene followed by $\mathrm{TM}_{1}$ and $\mathrm{TM}_{3}$ (Table 4). $\mathrm{TM}_{4}$ increased PAX7 levels compared to other TM groups, which reduced its levels significantly compared to controls. Finally, $\mathrm{TM}_{2}$ and $\mathrm{TM}_{4}$ increased PCNA levels compared to those of $\mathrm{TM}_{1}$ and $\mathrm{TM}_{3}$.

On ED 18, TM induced significant increases in MyoD levels compared to controls, but this effect was more pronounced in the $\mathrm{TM}_{4}$ group. TM induced a significant elevation in myogenin expression compared to controls, however, this effect was more pronounced in the $\mathrm{TM}_{4}$ group. Additionally, TM induced significant overexpression in IGF-1 and GH levels compared to controls, and $\mathrm{TM}_{2}$ induced overexpression of $\mathrm{GH}$ compared to other TM groups. Finally, TM induced significant elevation of the PAX7 and PCNA genes compared to controls.

Effects of thermal manipulation on mRNA expression levels of muscle growth factors (IGF-1 and GH) and muscle marker genes (MyoD, Myogenin, Pax7 and PCNA) on post-hatch days 1, 3, 5 and 7

On post-hatch 1, TM, except for $\mathrm{TM}_{2}$, induced significant elevation in MyoD levels, and the highest effect was reported in $\mathrm{TM}_{3}$. In contrast, myogenin expression was 


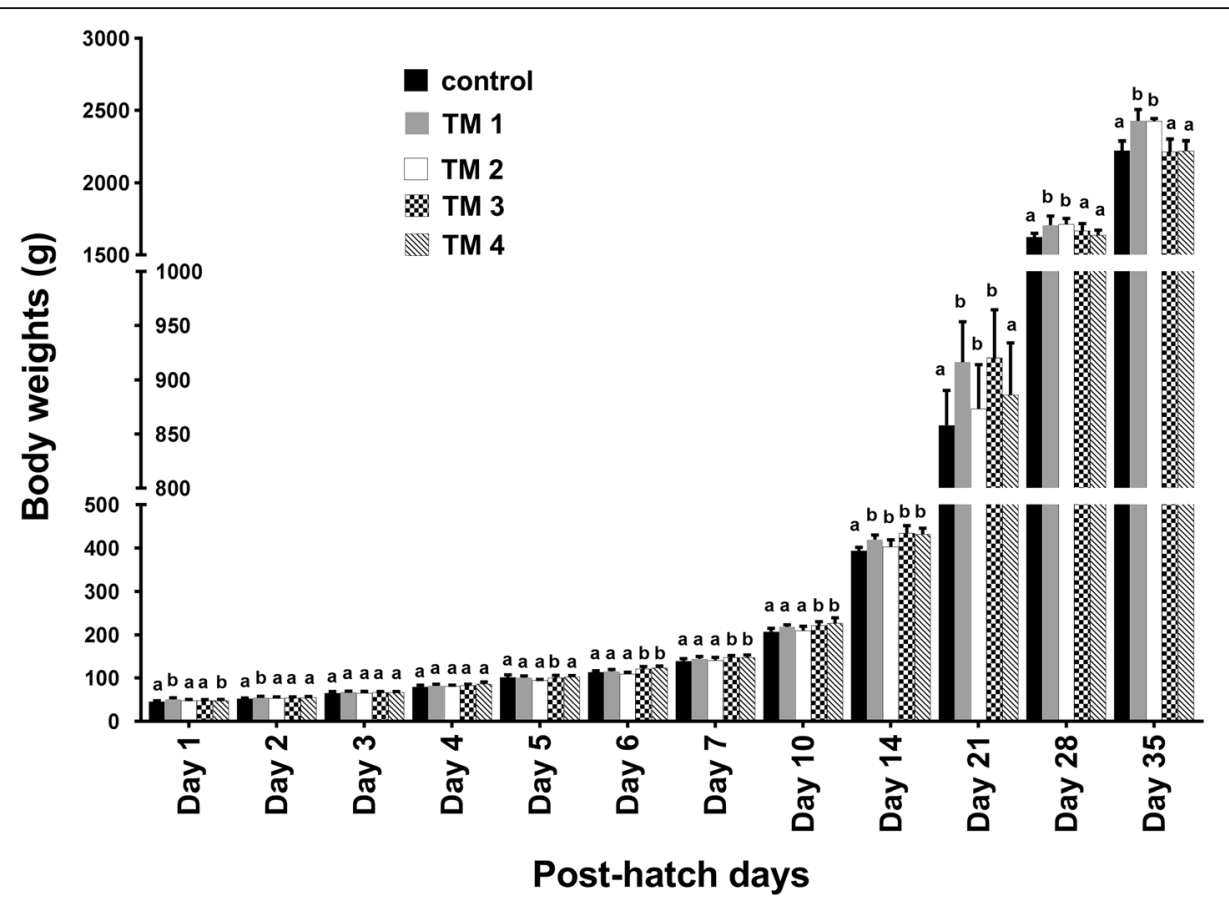

Fig. 2 The effect of thermal manipulation (TM) during embryogenesis on body weight in post-hatch broiler chicks from day 1 to day 35 ( $n=20)$. Control $=37.8^{\circ} \mathrm{C}$ for $24 \mathrm{~h} ; \mathrm{TM}_{1}=$ Thermal manipulation at $38.5^{\circ} \mathrm{C}$ for $18 \mathrm{~h} ; \mathrm{TM}_{2}=$ Thermal manipulation at $39^{\circ} \mathrm{C}$ for $18 \mathrm{~h} ; \mathrm{TM}_{3}=$ Thermal manipulation at $39.5^{\circ} \mathrm{Cfor} 18 \mathrm{~h}, \mathrm{TM}_{4}=$ Thermal manipulation at $40^{\circ} \mathrm{C}$ for $18 \mathrm{~h}$. ${ }^{\mathrm{a}-\mathrm{b}}$ Within the same day, means $\pm \mathrm{SD}$ with different superscripts differ significantly $(P<0.05)$

downregulated by $\mathrm{TM}$, except for $\mathrm{TM}_{1}$ which remained comparable to the controls, and the lowest myogenin expression was observed in $\mathrm{TM}_{2}$. TM induced significant reduction in IGF-1 levels compared to control, whereas no significant changes were documented in the GH levels of all TM groups on post-hatch days 1 and 3. Moreover, TM induced a significant increase in PAX7 levels compared to the control group on post-hatch days 1, 3, 5. 14, and 28. TM significantly decreased PCNA levels compared to controls.

On post-hatch day $3, \mathrm{TM}_{1}$ induced significant increases in MyoD and myogenin levels compared to

Table 3 Body weight, carcass weight, breast muscle weights and weight/or length of visceral organs at day 35 of age in broiler chicks subjected to different thermal manipulation protocols during embryonic life (ED12-18)

\begin{tabular}{|c|c|c|c|c|c|}
\hline \multirow[t]{2}{*}{ Parameters } & \multicolumn{5}{|l|}{ Groups } \\
\hline & Control & $\mathrm{TM}_{1}$ & $\mathrm{TM}_{2}$ & $\mathrm{TM}_{3}$ & $\mathrm{TM}_{4}$ \\
\hline Body weight & $2222.98 \pm 65.68^{\mathrm{a}}$ & $2426.64 \pm 70.39^{b}$ & $2425.78 \pm 17.29^{b}$ & $2216.22 \pm 85.39^{\mathrm{a}}$ & $2220.37 \pm 69.66^{\mathrm{a}}$ \\
\hline Carcass weight & $1423.90 \pm 69.46^{a}$ & $1568.87 \pm 24.83^{b}$ & $1569.27 \pm 16.36^{b}$ & $1521.52 \pm 06.69^{c}$ & $1515.92 \pm 06.75^{c}$ \\
\hline Breast muscle weight & $493.05 \pm 28.98^{\mathrm{a}}$ & $571.07 \pm 08.45^{\mathrm{b}}$ & $563.02 \pm 20.10^{b}$ & $580.54 \pm 54.39^{b}$ & $584.75 \pm 40.09^{b}$ \\
\hline Breast muscle weight/ Carcass weight $\%$ & $34.62 \pm 00.44^{a}$ & $37.12 \pm 01.04^{b}$ & $36.81 \pm 00.81^{b}$ & $37.62 \pm 00.90^{b}$ & $38.55 \pm 01.02^{b}$ \\
\hline Heart weight & $13.41 \pm 00.87^{\mathrm{a}}$ & $15.57 \pm 00.80^{b}$ & $15.54 \pm 00.70^{b}$ & $14.68 \pm 01.62^{a}$ & $14.53 \pm 01.76^{a}$ \\
\hline Lung weight & $13.46 \pm 00.01$ & $12.58 \pm 00.13$ & $13.08 \pm 00.50$ & $13.24 \pm 01.06$ & $12.30 \pm 02.12$ \\
\hline Spleen weight & $2.26 \pm 00.25$ & $2.45 \pm 00.45$ & $2.44 \pm 00.10$ & $2.33 \pm 00.94$ & $01.92 \pm 00.47$ \\
\hline Liver weight & $47.15 \pm 02.25^{a}$ & $56.00 \pm 03.47^{b}$ & $54.57 \pm 02.71^{\mathrm{b}}$ & $52.60 \pm 06.73^{b}$ & $51.52 \pm 02.26^{b}$ \\
\hline Intestine weight & $127.11 \pm 06.93$ & $130.40 \pm 10.85$ & $132.22 \pm 05.06$ & $131.82 \pm 00.69$ & $124.27 \pm 06.09$ \\
\hline Gizzard weight & $47.69 \pm 03.03^{a}$ & $45.51 \pm 00.13^{a}$ & $42.50 \pm 01.87^{\mathrm{a}}$ & $59.55 \pm 06.61^{b}$ & $46.84 \pm 01.92^{a}$ \\
\hline Intestine length & $167.33 \pm 02.31$ & $171.33 \pm 04.73$ & $164.67 \pm 01.53$ & $165.50 \pm 03.54$ & $165.67 \pm 04.40$ \\
\hline Cecum length & $17.00 \pm 01.00$ & $16.57 \pm 00.58$ & $17.00 \pm 01.00$ & $19.33 \pm 01.15$ & $17.03 \pm 01.00$ \\
\hline Colon length & $20.33 \pm 02.02^{a}$ & $16.67 \pm 00.58^{b}$ & $16.00 \pm 01.00^{b}$ & $18.67 \pm 01.53^{\mathrm{a}}$ & $16.67 \pm 00.58^{b}$ \\
\hline
\end{tabular}

TM: Thermal manipulation

${ }^{a-c}$ Within the same row, means \pm SD with different superscripts differ significantly $(P<0.05)$ 
Table 4 Relative mRNA levels of MyoD, Myogenin, IFG-1, GH, PAX7 and PCNA in the muscle tissues on embryonic days (ED) 12 and 18 in broiler chicks subjected to different thermal manipulation protocols during embryonic life (ED12-18)

\begin{tabular}{|c|c|c|c|c|c|c|}
\hline \multirow[t]{2}{*}{ ED } & \multirow[t]{2}{*}{ Parametrs } & \multicolumn{5}{|l|}{ Groups } \\
\hline & & Control & $\mathrm{TM}_{1}$ & $\mathrm{TM}_{2}$ & $\mathrm{TM}_{3}$ & $\mathrm{TM}_{4}$ \\
\hline \multirow[t]{6}{*}{ ED12 } & MyoD & $1 \pm 0.01^{a}$ & $1.11 \pm 0.02^{b}$ & $1.14 \pm 0.03^{b}$ & $1.02 \pm 0.03^{\mathrm{a}}$ & $1.63 \pm 0.07^{c}$ \\
\hline & Myogenin & $1 \pm 0.01^{a}$ & $1.38 \pm 0.03^{b}$ & $1.68 \pm 0.06^{c}$ & $0.94 \pm 0.02^{d}$ & $1.16 \pm 0.04^{e}$ \\
\hline & IGF-1 & $1 \pm 0.01^{\mathrm{a}}$ & $0.86 \pm 0.02^{b}$ & $0.92 \pm 0.03^{b}$ & $1.18 \pm 0.01^{c}$ & $1.55 \pm 0.08^{d}$ \\
\hline & $\mathrm{GH}$ & $1 \pm 0.05^{\mathrm{a}}$ & $8.90 \pm 0.04^{b}$ & $15.8 \pm 0.05^{c}$ & $1.47 \pm 0.04^{d}$ & $1.03 \pm 0.05^{\mathrm{a}}$ \\
\hline & PAX7 & $1 \pm 0.01^{\mathrm{a}}$ & $0.85 \pm 0.02^{b}$ & $0.92 \pm 0.04^{b}$ & $0.79 \pm 0.02^{b}$ & $1.38 \pm 0.04^{c}$ \\
\hline & PCNA & $1 \pm 0.01^{\mathrm{a}}$ & $1.07 \pm 0.02^{\mathrm{a}}$ & $1.11 \pm 0.01^{b}$ & $0.99 \pm 0.02^{\mathrm{a}}$ & $1.19 \pm 0.03^{b}$ \\
\hline \multirow[t]{6}{*}{ ED18 } & MyoD & $1 \pm 0.02^{a}$ & $1.59 \pm 0.02^{b}$ & $1.85 \pm 0.03^{b}$ & $1.88 \pm 0.03^{b}$ & $2.31 \pm 0.07^{c}$ \\
\hline & Myogenin & $1 \pm 0.11^{\mathrm{a}}$ & $2.57 \pm 0.53^{b}$ & $4.05 \pm 0.16^{c}$ & $2.79 \pm 0.12^{b}$ & $21.9 \pm 0.44^{d}$ \\
\hline & IGF-1 & $1 \pm 0.01^{\mathrm{a}}$ & $1.29 \pm 0.02^{b}$ & $1.72 \pm 0.03^{c}$ & $1.37 \pm 0.01^{b}$ & $1.85 \pm 0.05^{\mathrm{d}}$ \\
\hline & $\mathrm{GH}$ & $1 \pm 0.05^{\mathrm{a}}$ & $4.11 \pm 0.04^{b}$ & $18.60 \pm 0.05^{c}$ & $4.63 \pm 0.04^{b}$ & $5.33 \pm 0.25^{d}$ \\
\hline & PAX7 & $1 \pm 0.03^{\mathrm{a}}$ & $1.43 \pm 0.02^{b}$ & $1.21 \pm 0.04^{c}$ & $1.40 \pm 0.02^{b}$ & $2.18 \pm 0.07^{d}$ \\
\hline & PCNA & $1 \pm 0.06^{\mathrm{a}}$ & $2.93 \pm 0.02^{b}$ & $3.96 \pm 0.19^{c}$ & $2.12 \pm 0.10^{b}$ & $2.50 \pm 0.10^{b}$ \\
\hline
\end{tabular}

TM: Thermal manipulation; ED: embryonic day; MyoD: Myogenic differentiation gene; IGF-1: Insulin-like growth factor 1; GH: Growth hormone; Pax7: Paired box transcription factor; PCNA: Proliferating cell nuclear antigen

a-e Within the same row, means \pm SD with different superscripts differ significantly $(P<0.05)$

other TM groups. $\mathrm{TM}_{1}$ and $\mathrm{TM}_{4}$ significantly elevated IGF-1 and PCNA levels, whereas $\mathrm{TM}_{2}$ and $\mathrm{TM}_{3}$ significantly reduced IGF-1 levels compared to controls.

On post-hatch day $5, \mathrm{TM}_{3}$ and $\mathrm{TM}_{4}$ significantly reduced MyoD levels. TM, except for $\mathrm{TM}_{1}$, upregulated myogenin expression, with $\mathrm{TM}_{4}$ resulting in the highest myogenin expression. TM, except for $\mathrm{TM}_{1}$, significantly reduced IGF-1 levels. TM induced upregulation of GH expression, with the highest GH expression being observed in the $\mathrm{TM}_{4}$ and $\mathrm{TM}_{3}$ groups. Moreover, TM induced significant PCNA elevation compared to the controls.

On post-hatch day $7, \mathrm{TM}_{4}$ induced significant elevation in MyoD levels. $\mathrm{TM}_{1}$ and $\mathrm{TM}_{4}$ caused an elevation in myogenin expression, while $\mathrm{TM}_{3}$ significantly reduced it. TM increased IGF-1 levels but significantly reduced its levels. GH expression was significantly elevated by TM (except for $\mathrm{TM}_{3}$ ). No significant changes in the level of PAX7 expression have been detected in all treatment groups compared to controls. In addition, $\mathrm{TM}_{1}, \mathrm{TM}_{2}$ and $\mathrm{TM}_{4}$ increased the PCNA level compared to $\mathrm{TM}_{3}$ which remained comparable to the control (Table 5). The expression of this gene was more pronnunceed in tissues of $\mathrm{TM}_{4}$ compare to $\mathrm{TM}_{1}$ and $\mathrm{TM}_{2}$ (Table 5).

\section{Effects of thermal manipulation on mRNA expression levels of muscle growth factors (IGF-1 and GH) and muscle marker genes (MyoD, Myogenin, Pax7 and PCNA) on post-hatch days 14 and 28}

On post-hatch day 14, TM, except for $\mathrm{TM}_{1}$, induced significant elevation in MyoD levels, with the most pronounced expression being in $\mathrm{TM}_{3} . \mathrm{TM}_{1}, \mathrm{TM}_{2}$ and $\mathrm{TM}_{4}$ reduced myogenin and $\mathrm{GH}$ levels, while $\mathrm{TM}_{3}$ significantly elevated it compared to controls (Table 6). TM upregulated IGF-1 and PCNA gene expression compared to controls (Table 6). The expressions of IGF-1 gene was more pronnunceed in tissues of $\mathrm{TM}_{3}$ followed by $\mathrm{TM}_{2}>\mathrm{TM}_{4}>\mathrm{TM}_{1}$ (Table 6). $\mathrm{TM}_{2}, \mathrm{TM}_{3}$ and $\mathrm{TM}_{4}$ elevated PAX7 level compare to $\mathrm{TM}_{1}$ which remained comparable to control (Table 6). On post-hatch day 28 , TM induced significant elevation of MyoD levels compared to controls, and this effect was most noticeable in the $\mathrm{TM}_{2}$ group (Table 6). $\mathrm{TM}_{2}$ and $\mathrm{TM}_{4}$ significantly upregulated myogenin expression while $\mathrm{TM}_{1}$ downregulated myogenin expression compared to other $\mathrm{TM}_{3}$ and control (Table 6). TM upregulated the expression of IGF-1, GH, PAX7 and PCNA genes compared to controls (Table 6). Compared to control, the patterns of increase in expression of IGF-1, GH, PAX7 and PCNA genes followed these orders, respectively $\mathrm{TM}_{2}>\mathrm{TM}_{3}>$ $\mathrm{TM}_{4}>\mathrm{TM}_{1} ; \quad \mathrm{TM}_{2}>\mathrm{TM}_{3}=\mathrm{TM}_{4}>\mathrm{TM}_{1} ; \quad \mathrm{TM}_{2}>\mathrm{TM}_{4}>$ $\mathrm{TM}_{1}>\mathrm{TM}_{3} ; \mathrm{TM}_{2}=\mathrm{TM}_{4}>\mathrm{TM}_{1}=\mathrm{TM}_{3}$ (Table 6).

\section{Discussion}

Previously, TM during mid- or late-term broiler embryogenesis has been shown to enhance muscle hypertrophy due to the increasing proliferation and differentiation of both fetal and adult myoblasts, leading to an increased myogenic cell pool in the embryo and posthatch broilers $[15,20]$. In the current study TM1 $\left(38.5^{\circ} \mathrm{C}\right)$ and TM2 $\left(39^{\circ} \mathrm{C}\right)$ for $18 \mathrm{~h}$ did not affect the hatchability percentage while TM3 $\left(39.5^{\circ} \mathrm{C}\right)$ and $\mathrm{TM} 4\left(40^{\circ} \mathrm{C}\right)$ for $18 \mathrm{~h}$ reduced the hatcahbiltiy perecentage significantly compre to other groups incuding the control. Previous studies by others 
Table 5 Relative mRNA levels of MyoD, Myogenin, IFG-1, GH, PAX7 and PCNA in the muscle tissues at days 1, 3, 5, 7 post hatch in broiler chicks subjected to different thermal manipulation protocols during embryonic life (ED12-18)

\begin{tabular}{|c|c|c|c|c|c|c|}
\hline \multirow{2}{*}{$\begin{array}{l}\text { Post- } \\
\text { Hatch } \\
\text { days }\end{array}$} & \multirow[t]{2}{*}{ Parameters } & \multicolumn{5}{|l|}{ Groups } \\
\hline & & Control & $\mathrm{TM}_{1}$ & $\mathrm{TM}_{2}$ & $\mathrm{TM}_{3}$ & $\mathrm{TM}_{4}$ \\
\hline \multirow[t]{6}{*}{ Day 1} & MyoD & $1 \pm 0.01^{a}$ & $1.80 \pm 0.03^{b}$ & $1.13 \pm 0.02^{a}$ & $3.46 \pm 0.06^{c}$ & $1.25 \pm 0.02^{d}$ \\
\hline & Myogenin & $1 \pm 0.01^{a}$ & $0.89 \pm 0.02^{\mathrm{a}}$ & $0.25 \pm 0.02^{b}$ & $0.71 \pm 0.02^{c}$ & $0.69 \pm 0.02^{c}$ \\
\hline & IGF-1 & $1 \pm 0.01^{\mathrm{a}}$ & $0.63 \pm 0.02^{b}$ & $0.44 \pm 0.03^{b}$ & $0.39 \pm 0.01^{b}$ & $0.62 \pm 0.03^{b}$ \\
\hline & $\mathrm{GH}$ & $1 \pm 0.02^{\mathrm{a}}$ & $1.26 \pm 0.01^{b}$ & $1.15 \pm 0.01^{c}$ & $1.15 \pm 0.04^{c}$ & $1.09 \pm 0.01^{c}$ \\
\hline & PAX7 & $1 \pm 0.01^{a}$ & $1.82 \pm 0.01^{b}$ & $1.40 \pm 0.06^{c}$ & $1.91 \pm 0.07^{b}$ & $1.21 \pm 0.07^{c}$ \\
\hline & PCNA & $1 \pm 0.01^{a}$ & $0.65 \pm 0.02^{b}$ & $0.55 \pm 0.02^{b}$ & $0.40 \pm 0.02^{b}$ & $0.31 \pm 0.02^{b}$ \\
\hline \multirow[t]{6}{*}{ Day 3} & MyoD & $1 \pm 0.01^{a}$ & $2.46 \pm 0.03^{b}$ & $0.82 \pm 0.02^{a}$ & $0.65 \pm 0.02^{a}$ & $1.22 \pm 0.02^{\mathrm{a}}$ \\
\hline & Myogenin & $1 \pm 0.01^{\mathrm{a}}$ & $2.05 \pm 0.03^{b}$ & $1.28 \pm 0.03^{\mathrm{a}}$ & $0.59 \pm 0.02^{\mathrm{a}}$ & $1.46 \pm 0.01^{a}$ \\
\hline & IGF-1 & $1 \pm 0.01^{a}$ & $2.47 \pm 0.06^{b}$ & $0.63 \pm 0.03^{d}$ & $0.65 \pm 0.03^{d}$ & $1.56 \pm 0.03^{c}$ \\
\hline & $\mathrm{GH}$ & $1 \pm 0.02^{\mathrm{a}}$ & $1.73 \pm 0.06^{b}$ & $1.01 \pm 0.01^{\mathrm{a}}$ & $0.04 \pm 0.04^{c}$ & $1.55 \pm 0.01^{b}$ \\
\hline & PAX7 & $1 \pm 0.02^{a}$ & $3.29 \pm 0.04^{b}$ & $1.55 \pm 0.01^{c}$ & $1.46 \pm 0.02^{c}$ & $1.99 \pm 0.02^{c}$ \\
\hline & PCNA & $1 \pm 0.03^{\mathrm{a}}$ & $3.18 \pm 0.09^{b}$ & $1.05 \pm 0.01^{\mathrm{a}}$ & $1.03 \pm 0.02^{\mathrm{a}}$ & $1.63 \pm 0.05^{c}$ \\
\hline \multirow[t]{6}{*}{ Day 5} & MyoD & $1 \pm 0.02^{a}$ & $0.95 \pm 0.03^{\mathrm{a}}$ & $0.79 \pm 0.03^{a}$ & $0.35 \pm 0.02^{b}$ & $0.13 \pm 0.01^{b}$ \\
\hline & Myogenin & $1 \pm 0.06^{a}$ & $1.45 \pm 0.02^{\mathrm{a}}$ & $3.49 \pm 0.23^{b}$ & $4.36 \pm 0.19^{c}$ & $10.54 \pm 0.27^{\circ}$ \\
\hline & IGF-1 & $1 \pm 0.02^{a}$ & $1.33 \pm 0.05^{a}$ & $0.64 \pm 0.03^{\mathrm{a}}$ & $0.34 \pm 0.01^{b}$ & $0.15 \pm 0.01^{b}$ \\
\hline & $\mathrm{GH}$ & $1 \pm 0.03^{\mathrm{a}}$ & $1.37 \pm 0.06^{a}$ & $6.77 \pm 0.02^{b}$ & $7.27 \pm 0.02^{c}$ & $8.50 \pm 0.07^{d}$ \\
\hline & PAX7 & $1 \pm 0.03^{\mathrm{a}}$ & $1.11 \pm 0.04^{b}$ & $1.51 \pm 0.02^{b}$ & $1.17 \pm 0.01^{b}$ & $1.15 \pm 0.03^{b}$ \\
\hline & PCNA & $1 \pm 0.09^{a}$ & $1.33 \pm 0.04^{\mathrm{a}}$ & $1.31 \pm 0.02^{\mathrm{a}}$ & $1.69 \pm 0.06^{b}$ & $5.01 \pm 0.13^{c}$ \\
\hline \multirow[t]{6}{*}{ Day 7} & MyoD & $1 \pm 0.04^{a}$ & $1.46 \pm 0.11^{\mathrm{a}}$ & $1.10 \pm 0.03^{\mathrm{a}}$ & $1.12 \pm 0.04^{a}$ & $2.09 \pm 0.06^{b}$ \\
\hline & Myogenin & $1 \pm 0.01^{a}$ & $2.04 \pm 0.22^{b}$ & $1.28 \pm 0.05^{a}$ & $0.05 \pm 0.19^{d}$ & $4.63 \pm 0.19^{c}$ \\
\hline & IGF-1 & $1 \pm 0.07^{\mathrm{a}}$ & $1.54 \pm 0.11^{b}$ & $1.70 \pm 0.05^{b}$ & $1.65 \pm 0.03^{b}$ & $0.14 \pm 0.02^{c}$ \\
\hline & $\mathrm{GH}$ & $1 \pm 0.01^{a}$ & $2.44 \pm 0.15^{b}$ & $1.37 \pm 0.07^{a}$ & $1.02 \pm 0.20^{a}$ & $5.80 \pm 0.10^{d}$ \\
\hline & PAX7 & $1 \pm 0.03$ & $1.01 \pm 0.06$ & $1.18 \pm 0.05$ & $1.01 \pm 0.01$ & $1.01 \pm 0.03$ \\
\hline & PCNA & $1 \pm 0.03^{\mathrm{a}}$ & $1.65 \pm 0.06^{b}$ & $1.28 \pm 0.05^{b}$ & $1.01 \pm 0.06^{\mathrm{a}}$ & $2.56 \pm 0.20^{c}$ \\
\hline
\end{tabular}

TM: Thermal manipulation; MyoD: Myogenic differentiation gene; IGF-1: Insulin-like growth factor 1; GH: Growth hormone; Pax7: Paired box transcription factor; PCNA: Proliferating cell nuclear antigen. ${ }^{\text {a-d }}$ Within the same row, means \pm SD with different superscripts differ significantly $(P<0.05)$

have reported that TM $\left(40^{\circ} \mathrm{C}\right)$ for $24 \mathrm{~h}$ at ED16-18 [22] and TM $\left(39.5^{\circ} \mathrm{C}\right)$ for 12 or $24 \mathrm{~h}$ at ED7-16 [10, 11] resulted in the improvement of thermotolerance acquisition, with a significant adverse effect on hatchability of broiler chickens. While TM $\left(39.5^{\circ} \mathrm{C}\right)$ for 3,12 or $24 \mathrm{~h}$ at ED16-18 had not only improved thermotolerance acquisition, but also resulted in an enhanced hatchability [9].

In this study, TM did not affect the embryonic weights of broiler chicken during ED 12 and 18. This finding agrees with previous report [23] using other themal manipulation protocols $\left(39.6^{\circ} \mathrm{C}\right.$ at $60 \%$ relative humidity for $6 \mathrm{~h}$ daily from 0 to 8 th day, and $39.6^{\circ} \mathrm{C}$ at $60 \%$ relative humidity for $6 \mathrm{~h}$ daily from the 10 to 18 th day) in broiler chickens. Earlier report [24] demonstrated thatTM $\left(39.5^{\circ} \mathrm{C}\right.$ and $65 \% \mathrm{RH}$ for $12 \mathrm{~h} / \mathrm{d}$ from ED7 to ED16) did not affect the male BW but females BW were lower than that of male during the entire 70 day posthatching study in broilers chicken.

However, BW and internal organ weights of hatched chicks were increased significantly as a result of TM, particularly chicks in the $\mathrm{TM}_{1}$ and $\mathrm{TM}_{2}$ groups near to the marketing age (post-hatch days 28 and 35). Conversely, embryos subjected to $\mathrm{TM}\left(39.5^{\circ} \mathrm{C}\right.$ during ED 12-18 for $6 \mathrm{~h}$ daily), during satellite cell population expansion experienced increased myofiber diameters and absolute muscle growth in treated chicks relative to controls until post-hatch day 35 [20]. In addition, it has been reported that mild heat exposure at an early age results in the acceleration of satellite cell myogenesis mediated by specific local growth factor expression [25]. This confliction can be attributed to the incubation period differences in the current study contrasted with other reports. The significant increase in weights of liver and heart tissues as a result of TM in the current study disagrees with previours reports in ostrrish [26] and Egyptian chickens [27] exposed to high incubation temperature during their late embryonic life. The significant increase in the breast muscles of birds exposed to TM of the 
Table 6 Relative mRNA levels of MyoD, Myogenin, IFG-1, GH, PAX7 and PCNA in the muscle tissues at days 14 and 28 post hatch in broiler chicks subjected to different thermal manipulation protocols during embryonic life (ED12-18)

\begin{tabular}{|c|c|c|c|c|c|c|}
\hline \multirow{2}{*}{$\begin{array}{l}\text { Post- } \\
\text { Hatch } \\
\text { days }\end{array}$} & \multirow[t]{2}{*}{ Parameters } & \multicolumn{5}{|l|}{ Groups } \\
\hline & & Control & $\mathrm{TM}_{1}$ & $\mathrm{TM}_{2}$ & $\mathrm{TM}_{3}$ & $\mathrm{TM}_{4}$ \\
\hline \multirow[t]{6}{*}{ Day 14} & MyoD & $1 \pm 0.03^{a}$ & $1.16 \pm 0.06^{\mathrm{a}}$ & $1.53 \pm 0.03^{b}$ & $2.29 \pm 0.01^{c}$ & $1.64 \pm 0.07^{b}$ \\
\hline & Myogenin & $1 \pm 0.06^{\mathrm{a}}$ & $0.44 \pm 0.02^{b}$ & $0.79 \pm 0.03^{c}$ & $1.67 \pm 0.06^{d}$ & $0.49 \pm 0.01^{b}$ \\
\hline & IGF-1 & $1 \pm 0.04^{a}$ & $1.40 \pm 0.04^{b}$ & $1.92 \pm 0.05^{c}$ & $2.25 \pm 0.02^{d}$ & $1.60 \pm 0.09^{e}$ \\
\hline & $\mathrm{GH}$ & $1 \pm 0.01^{\mathrm{a}}$ & $0.39 \pm 0.01^{b}$ & $0.56 \pm 0.07^{b}$ & $1.40 \pm 0.06^{c}$ & $0.51 \pm 0.01^{b}$ \\
\hline & PAX7 & $1 \pm 0.03^{a}$ & $1.09 \pm 0.06^{\mathrm{a}}$ & $1.34 \pm 0.05^{b}$ & $2.02 \pm 0.01^{c}$ & $1.29 \pm 0.03^{b}$ \\
\hline & PCNA & $1 \pm 0.03^{\mathrm{a}}$ & $1.28 \pm 0.05^{b}$ & $1.63 \pm 0.03^{b}$ & $1.56 \pm 0.06^{b}$ & $1.73 \pm 0.04^{b}$ \\
\hline \multirow[t]{6}{*}{ Day 28} & MyoD & $1 \pm 0.03^{\mathrm{a}}$ & $1.55 \pm 0.03^{b}$ & $3.44 \pm 0.11^{c}$ & $1.53 \pm 0.02^{b}$ & $1.78 \pm 0.01^{b}$ \\
\hline & Myogenin & $1 \pm 0.06^{a}$ & $0.10 \pm 0.22^{b}$ & $4.44 \pm 0.05^{c}$ & $1.04 \pm 0.08^{\mathrm{a}}$ & $1.30 \pm 0.02^{d}$ \\
\hline & IGF-1 & $1 \pm 0.04^{\mathrm{a}}$ & $1.48 \pm 0.07^{b}$ & $3.53 \pm 0.05^{c}$ & $2.99 \pm 0.05^{d}$ & $2.53 \pm 0.07^{\mathrm{e}}$ \\
\hline & $\mathrm{GH}$ & $1 \pm 0.01^{\mathrm{a}}$ & $1.12 \pm 0.01^{b}$ & $4.09 \pm 0.07^{d}$ & $1.93 \pm 0.05^{c}$ & $1.17 \pm 0.06^{c}$ \\
\hline & PAX7 & $1 \pm 0.03^{a}$ & $1.96 \pm 0.06^{b}$ & $3.44 \pm 0.13^{c}$ & $1.53 \pm 0.06^{d}$ & $2.21 \pm 0.13^{b}$ \\
\hline & PCNA & $1 \pm 0.03^{a}$ & $1.15 \pm 0.02^{b}$ & $1.89 \pm 0.16^{c}$ & $1.19 \pm 0.03^{b}$ & $1.63 \pm 0.05^{c}$ \\
\hline
\end{tabular}

TM: Thermal manipulation; MyoD: Myogenic differentiation gene; IGF-1: Insulin-like growth factor 1; GH: Growth hormone; Pax7: Paired box transcription factor; PCNA: Proliferating cell nuclear antigen

a-e Within the same row, means \pm SD with different superscripts differ significantly $(P<0.05)$

current study are in the line with that obesreved earlier $[10,28]$ in the broiles chickens.

Myoblast proliferation and differentiation processes are controlled by the muscle-specific basic helix-looposthatch elix (bHLH) family of transcription factors [5]. The MyoD family contains four basic helix-loop-helix (bHLH) transcription factors (MyoD, myogenic factor-5 (Myf5), myogenin, and myogenic regulatory factor-4 (MRF4) and positively regulates myogenesis [5]. These factors are expressed in a sequential pattern when satellite cells are activated [5]. Initially, Myf5 and MyoD are expressed in the proliferating progeny, after which myogenin is expressed as the cells begin to differentiate [29]. The current findings showed that TM resulted in immediate stimulation of muscular MyoD mRNA expression in all TM groups on ED 12 and 18, with the highest expression being detected in $\mathrm{TM}_{4}$. At post-hatch days 14, and 28, a significant increase in MyoD expression was observed in all TM groups. It seems that TM has early- (ED 12 and 18) and late-term (post-hatch days 7, 14 and 28) effects in myoblast proliferation as indicated by the increase of MyoD mRNA expression. In this study, TM resulted in immediate stimulation of muscular myogenin mRNA expression on ED 18 in all TM groups. On post-hatch day 28 , a higher expression of myogenin was only observed in the $\mathrm{TM}_{2}$ and $\mathrm{TM}_{3}$ groups. Similarly, it has been reported that TM $\left(39.5^{\circ} \mathrm{C}\right.$ at ED 12-18 for 3 and $6 \mathrm{~h}$ ) resulted in the enhancement of cell differentiation as indicated by muscular myogenin expression levels [20]. The current findings indicate that TM resulted in an immediate stimulation (early-term effect) of myogenin mRNA expression during embryogenesis and a delayed stimulation on post-hatch days 7, 14 and 28 (late-term effect). These results are in contrast with the previous findings [20] which reported that the increase of muscle hypertrophy in heat-treated chicks was similar,regardless of TM length ( $3 \mathrm{~h}$ vs $6 \mathrm{~h}$ ).

Pax7 has been suggested as an early marker of myogenesis during post-hatch muscle growth, and its expression is sustained by satellite cells in adult chicken muscle [30, 31]. Pax7 plays a key role in the formation of adult mouse skeletal muscle [32]. Furthermore, Pax7 is expressed during myoblast proliferation and decreases during differentiation [30]. The results of the current study illustrated that TM resulted in immediate stimulation of muscular Pax7 mRNA expression on ED 12 and 18, with a higher expression of Pax7 detected in $\mathrm{TM}_{4}$. Furthermore, Pax7 expression significantly increased on post-hatch days $1,3,5,14$, and 28 .

Previous study [20] reported that, TM $\left(39.5^{\circ} \mathrm{C}\right.$ at ED 12-18) resulted in immediate (ED17) and later (up to 2 weeks post-hatch) effects in myoblast proliferation as indicated by higher DNA incorporation of thymidine, higher number of muscle cells expressing PCNA in intact muscle, and higher Pax7 protein levels. The aforementioned study suggested that TM enhanced muscle hypertrophy by stimulation of the myogenic progeny cell (satellite cell) proliferation. In this study, $\mathrm{TM}_{2}$ and $\mathrm{TM}_{4}$ resulted in a significant increase of muscular PCNA mRNA expression, and the highest PCNA expression was detected on ED 12 and 18 as well as on post-hatch days 7,14 , and 28 .

In mammals and birds, muscle cell proliferation and differentiation are controlled by growth factors and 
hormones that play a pivotal role in promoting the growth of skeletal muscle [33]. One of the most important growth factors that regulates the proliferation of satellite cells is insulin growth factor-1 (IGF-1), the latter of which plays a role in both muscle growth and hypertrophy via its effect on satellite cells [33, 34]. Previously, a higher level of IGF-1 gene expression was observed in chicken breast muscle tissues in response to early age TM (24 h on post-htach day 3) [25], TM at $38.5^{\circ} \mathrm{C}$ on ED 12 to 18 [35], and $\mathrm{TM}$ at $39.5^{\circ} \mathrm{C}$ on ED 12 to 18 [20]. In this study, TM resulted in the immediate stimulation of muscular IGF-1 mRNA expression during ED 18 and on post-hatch days $5,7,14$, and 28 . This increase of IGF-1 expression was associated with significant increases in BW of thermally manipulated chicks on posthatch days 28 and 35 .

Growth hormone plays a pivotal role in promoting the growth of mammalian skeletal muscle, and it has been shown that administration of GH to humans, ruminants, and pigs enhanced their skeletal muscle growth [36-41]. Interestingly, IGF-I has been suggested to mediate the effect of GH on muscle growth, as IGF-I mRNA levels are also stimulated in liver tissue and skeletal muscle as a result of GH administration [38]. The current data indicate that TM resulted in immediate stimulation of muscular GH mRNA expression on ED 12 and 18 and on post-hatch days 7 and 14 in all TM groups, while, on post-hatch day 28 , the only significant increase observed is in the $\mathrm{TM}_{3}$ group. However, the regulation of IGF-1 and muscle tissues growth by $\mathrm{GH}$ of pituitary origin can not be ignored.

\section{Conclusion}

Together, these findings suggest a differential effect of various TM periods on muscle growth and development and it appears that $\mathrm{TM}_{1}$ and $\mathrm{TM}_{2}$ presented the optimum conditions for its enhancement. This was evident by the significant increases in embryonic and post-hatch BW on days 28 and 35 . This improvement in BW was associated with immediate and longlasting effects of TM in the expression of muscle growth factors (IGF-1 and GH) and muscle marker genes (MyoD, Myogenin, Pax7, and PCNA). The current study concluded that TM improved the BW and up-regulated the muscle growth factor and marker genes. Moreover, it seems that $\mathrm{TM}_{1}$ and $\mathrm{TM}_{2}$ were superior protocols that can be used to attain the objectives of the current study.

\footnotetext{
Abbreviations

ANOVA: Analysis of variance; bHLH: Basic helix-loop-helix; BW: Body weight; ED: Embryonic days; GH: Growth hormone; IGF-1: Insulin-like growth factor 1; MRF4: Myogenic regulatory factor-4; Myf5: Myogenic factor-5;

MyoD: Myogenic differentiation gene; Pax7: Paired box transcription factor; PCNA: Proliferating cell nuclear antigen; RH: Relative humidity; TM: Thermal manipulation
}

\section{Acknowledgments}

Authors thank Dr. Mustafa Ababneh, Dr. Khaleel Jawasreh and Eng. Ibrahim Alshokani for their excellent technical assistance and valuable comments. The authors would like to express a deep appreciation and thanks to the Deanship of Research/ Jordan University of Science \& Technology for its financial support of this work (Grant\#: 66/2016).

\section{Authors' contributions}

MBA and SME are equally contributed in the study. MBA carried out the experimental design and participated in hatching management, thermal manipulation and heat challenge, sequence alignment, RNA isolation, RT-PCR and performed the statistical analysis. SME carried out hatching management and participated in experimental design, thermal manipulation, heat challenge, sequence alignment, RNA isolation and RT-PCR. MBA and SME drafted and approved the final version of the manuscript.

\section{Funding \\ This project was funded by Deanship of Research/ Jordan University of Science \& Technology (Grant number: 66/2016).}

\section{Availability of data and materials}

The datasets used and/or analyzed during the current study are available from the corresponding author on reasonable request.

\section{Ethics approval}

All experimental procedures and management conditions used in this study were approved by the Jordan University of Science and technology Animal Care and Use Committee (JUST-ACUC; permission \#16/3/3/390).

\section{Consent for publication}

Not applicable - Avian study, no human subjects.

\section{Competing interests}

The authors declare that they have no competing interests.

\section{Publisher's Note}

Springer Nature remains neutral with regard to jurisdictional claims in published maps and institutional affiliations.

\section{Author details}

${ }^{1}$ Department of Basic Medical Veterinary Sciences, Faculty of Veterinary Medicine, Jordan University of Science and Technology, P.O. Box 3030, Irbid 22110, Jordan. ${ }^{2}$ Department of Physiology, Biochemistry and Pharmacology, College of Veterinary Medicine, King Faisal University, P.O. Box 400, Al-Hufof 31982, Saudi Arabia. ${ }^{3}$ Department of Biochemistry, Faculty of Veterinary Medicine, Alexandria University, Alexandria, Egypt.

Received: 10 December 2018 Accepted: 16 May 2019

Published online: 23 May 2019

\section{References}

1. Allen RE, Merkel RA, Young RB. Cellular aspect of muscle growth: myogenic cell proliferation. J Anim Sci. 1979;49:115-27.

2. Braun T, Gautel M. Transcriptional mechanisms regulating skeletal muscle differentiation, growth and homeostasis. Nature Reviews Mol Cell Biol. 2011;12:349-61.

3. Olson EN. Interplay between proliferation and differentiation within the myogenic lineage. Dev Biol. 1992;154:261-72.

4. Hawke TJ, Garry DJ. Myogenic satellite cells: physiology to molecular biology. J Appl Physiol. 2001;91:534-51.

5. Weintraub $H$. The MyoD family and myogenesis: redundancy, networks, and thresholds. Cell. 1993;75:1241-4.

6. Figarella-Branger D, Pellissier JF, Bianco N, Karpati G. Sequence of expression of MyoD1 and various cell surface and cytoskeletal proteins in regenerating mouse muscle fibers following treatment with sodium dihydrogen phosphate. J Neurol Sci. 1999;170:151-60.

7. Cornelison DD, Wold BJ. Single-cell analysis of regulatory gene expression in quiescent and activated mouse skeletal muscle satellite cells. Dev Biol. 1997;191:270-83.

8. Yalcin S, Siegel P. Exposure to cold or heat during incubation on developmental stability of broiler embryos. Poult Sci. 2003;82:1388-92. 
9. Yahav S, Rath R, Sasson A, Shinder D. The effect of thermal manipulations during embryogenesis of broiler chicks (Gallus domesticus) on hatchability, body weight and thermoregulation after hatch. J Therm Biol. 2004:29:245-50.

10. Piestun Y, Ruzal M, Shinder D, Halevy O, Yahav S. The effect of thermal manipulations during the development of the thyroid and adrenal axes on in-hatch and post-hatch thermoregulation. J Therm Biol. 2008a;33:413-8.

11. Piestun Y, Shinder D, Ruzal M, Halevy O, Brake J, Yahav S. Thermal manipulations during broiler embryogenesis: effect on the acquisition of thermotolerance. Poult Sci. 2008b;87:1516-25.

12. Al-Zghoul MB, Dalab AE, Ababneh MM, Jawasreh $\mathrm{Kl}$, Al Busadah KA, Ismail ZB. Thermal manipulation during chicken embryogenesis results in enhanced Hsp70 gene expression and the acquisition of thermotolerance. Res Vet Sci. 2013;95:502-7.

13. Al-Zghoul MB, Al-Natour MQ, Dalab AS, Alturki Ol, Althnaian T, Al-ramadan SY, Hannon KM, El-Bahr SM. Thermal manipulation mid-term broiler chicken embryogenesis: effect on muscle growth factors and muscle marker genes. Braz J Poult Sci. 2016;18:607-18.

14. Al-Zghoul MB, Ismail ZB, Dalab AE, Al-Ramadan A, Althnaian TA, Al-Ramadan SY, Ali AM, Albokhadaim IF, Al Busadah KA, Eljarah A, Jawasreh Kl, Hannon KM. Hsp90, Hsp60 and HSF-1 genes expression in muscle, heart and brain of thermally manipulated broiler chicken. Res Vet Sci. 2015;99:105-11.

15. Piestun $Y$, Yahav $S$, Halevy $O$. Thermal manipulation during embryogenesis affects myoblast proliferation and skeletal muscle growth in meat-type chickens. Poult Sci. 2015;94:2528-36.

16. Decuypere $\mathrm{E}$, Michels $\mathrm{H}$. Incubation-temperature as a management tool-a review. World's Poult Sci J. 1992;48:28-38.

17. Lourens A, Van den Brand H, Meijerhof R, Kemp B. Effect of eggshell temperature during incubation on embryo development, hatchability, and posthatch development. Poult Sci. 2005;84:914-20.

18. Loyau T, Hennequet-Antier C, Coustham V, Berri C, Leduc M, Crochet S, Sannier M, Duclos MJ, Mignon-Grasteau S, Tesseraud S, Brionne A, Métayer-Coustard S, Moroldo M, Lecardonnel J, Martin P, Lagarrigue S, Yahav S, Collin A. Thermal manipulation of the chicken embryo triggers differential gene expression in response to a later heat challenge. BMC Genomics. 2016;17:329-44.

19. Naraballobh W, Trakooljul N, Murani E, Krischek C, Janisch S, Wicke M, Ponsuksili S, Wimmers K. miRNAs regulate acute transcriptional changes in broiler embryos in response to modification of incubation temperature. Sci Rep. 2018;8:11371-83.

20. Piestun $Y$, Harel M, Barak M, Yahav S, Halevy O. Thermal manipulations in late-term chick embryos have immediate and longer term effects on myoblast proliferation and skeletal muscle hypertrophy. J Appl Physiol. 2009;106:233-40.

21. Overmyer KA, Thonusin C, Qi NR, Burant CF, Evans CR. Impact of anesthesia and euthanasia on metabolomics of mammalian tissues: studies in a C57BL/ 6J mouse model. PLoS One. 2015;10(2):e0117232.

22. Willemsen H, Kamers B, Dahlke F, Han H, Son Z, Ansari Pirsaraei Z, Tona K, Decuypere E, Everaert N. High- and low-temperature manipulation during late incubation: effects on embryonic development, the hatching process, and metabolism in broilers. Poul Sci. 2010;89:2678-90.

23. Narinc D, Erdoğan S, Tahtabiçen E, Aksoy T. Effects of thermal manipulations during embryogenesis of broiler chickens on developmental stability, hatchability and chick quality. Animal. 2016;10:1328-35.

24. Piestun Y, Druyan S, Brake J, Yahav S. Thermal manipulations during broiler incubation alter performance of broilers to 70 days of age. Poult Sci. 2013;92:1155-63.

25. Halevy O, Krispin A, Leshem Y, McMurtry JP, Yahav S. Early-age heat exposure affects skeletal muscle satellite cell proliferation and differentiation in chicks. Am J Physiol Regul Integr Comp Physiol. 2001;281:302-9.

26. Elsayed NAM. Effects of thermal manipulation during late incubation period on post-hatch thermotolerance in ostrich. Czech J Anim Sci. 2016;61:421-31.

27. Elsayed NAM, Elkomy AE, El-Saadany AS, Hassan EY. New suggested schemes for incubation temperature and their effect on embryonic development and hatching power. Asian J Poult Sci. 2009:3:19-29.

28. Piestun Y, Halevy O, Shinder D, Ruzal M, Druyan S, Yahav S. Thermal manipulations during broiler embryogenesis improves post hatch performance under hot conditions. Therm Biol. 2011;36:469-74.

29. Beauchamp JR, Heslop L, Yu D, Tajbakhsh S, Kelly R, Wernig A, Buckingham ME, Partridge TA, Zammit PS. Expression of CD34 and Myf5 defines the majority of quiescent adult skeletal muscle satellite cells. J Cell Biol. 2000;151:1221-33.
30. Halevy O, Piestun Y, Allouh MZ, Rosser BW, Rinkevich Y, Reshef R, Rozenboim I, Wleklinski-Lee M, Yablonka-Reuveni Z. Pattern of Pax7 expression during myogenesis in the posthatch chicken establishes a mode for satellite cell differentiation and renewal. Dev Dyn. 2004;231:489-502.

31. Allouh MZ, Yablonka-Reuveni Z, Rosser BW. Pax7 reveals a greater frequency and concentration of satellite cells at the ends of growing skeletal muscle fibers. J Histochem Cytochem. 2008;56:77-87.

32. Seale P, Sabourin LA, Givgis-Gabardo A, Mansuori A, Gruss P, Rudnicki MA. Pax7 is required for the specification of myogenic satellite cells. Cell. 2000;102:777-86.

33. Adams GR, Haddad F, Baldwin KM. Time course of changes in markers of myogenesis in overloaded rat skeletal muscles. J Appl Physiol. 1999:87:1705-12.

34. Adams GR, McCue SA. Localized infusion of IGF-I results in skeletal muscle hypertrophy in rats. J Appl Physiol. 1998:84:1716-22.

35. Halevy O, Yahav S, Rozenboim I. Enhancement of meat production by environmental manipulation in embryo and young broilers. World's Poult Sci J. 2006;62:485-97.

36. Chung CS, Etherton TD, Wiggins JP. Stimulation of swine growth by porcine growth hormone. J Anim Sci. 1985;60:118-30.

37. Campbell RG, Steele NC, Caperna TJ, McMurtry JP, Solomon MB, Mitchell AD. Interrelationships between sex and exogenous growth hormone administration on performance, body composition and protein and fat accretion of growing pigs. J Anim Sci. 1989;67:177-86.

38. Grant AL, Helferich WG, Kramer SA, Merkel RA, Bergen WG. Administration of growth hormone to pigs alters the relative amount of insulin-like growth factor-I mRNA in liver and skeletal muscle. J Endocrinol. 1991;130:331-8.

39. Brameld JM, Atkinson JL, Saunders JC, Pell JM, Buttery PJ, Gilmour RS. Effects of growth hormone administration and dietary protein intake on insulin-like growth factor I and growth hormone receptor mRNA expression in porcine liver, skeletal muscle, and adipose tissue. J Anim Sci. 1996;74:1832-41.

40. Tavares AB, Micmacher E, Biesek S, Assumpcao R, Redorat R, Veloso U, Vaisman M, Farinatti PT, Conceicao F. Effects of growth hormone administration on muscle strength in men over 50 years old. Int J Endocrinol. 2013:94:20-30.

41. Jiang H, Ge X. Meat science and muscle biology symposium - mechanism of growth hormone stimulation of skeletal muscle growth in cattle. J Anim Sci. 2014;92:21-9.
Ready to submit your research? Choose BMC and benefit from:

- fast, convenient online submission

- thorough peer review by experienced researchers in your field

- rapid publication on acceptance

- support for research data, including large and complex data types

- gold Open Access which fosters wider collaboration and increased citations

- maximum visibility for your research: over $100 \mathrm{M}$ website views per year

At $\mathrm{BMC}$, research is always in progress.

Learn more biomedcentral.com/submission 